\title{
Sulfur isotopic ratios of hydrothermal vent-animals at Ogasawara Arc and Mid-Okinawa Trough-evidence for microbial origin of hydrogen sulfide at low-temperature submarine hydrothermal areas
}

\author{
Eun SOo KIM ${ }^{1}$, Hitoshi SaKai ${ }^{1}$, Jun HaShimoto ${ }^{2}$, \\ Fumitaka Yanagisawa ${ }^{1}$ and Suguru OHTA ${ }^{1}$ \\ Ocean Research Institute, University of Tokyo, 1-15-1 Minamidai, Nakano-ku, Tokyo $164^{1}$ \\ and Japan Marine Science and Technology Center, Natsushima 2-15, \\ Yokosuka, Kanagawa-Pref. $237^{2}$, Japan
}

(Received August 17, 1989; Accepted December 16, 1989)

\begin{abstract}
A mussel, clams, vestimentiferan tube worms and squat lobsters from vent-communities at three volcanically active sites, the Kaikata Caldera of Ogasawara Arc and the Minami-Ensei Knoll and the eastern Iheya Ridge of Okinawa Trough, were analyzed for the concentration and isotopic ratio of sulfur in their soft tissues. The results indicate that the mussel, clams and tube worms are nutritionally supported by endosymbiosis with chemolithotrophic sulfur-oxidizing bacteria which utilize hydrogen sulfide in venting fluid as energy source for organic carbon synthesis, while the squat lobsters live on the chemosynthetic food web. However, the sulfur isotopic ratios of these animals range from -10 to $-26 \%$, much lower than the volcanic sulfur values of these areas $(0 \sim+10 \%)$. This implies that in all the three sites, hydrogen sulfide produced by sulfate-reducing bacteria is an important sulfur source for vent communities. The sulfur flux required for the biological communities is an order of magnitude or two greater than that encountered in normal organic-rich marine sediments. It is suggested that the high heat flow, porous volcanogenic sediments and organic materials accumulated by biological communities play important roles in maintaining high production rate of microbial hydrogen sulfide and its efficient transport to surface in volcanically active seafloor.
\end{abstract}

\section{INTRODUCTION}

Biological communities dominated by clams, mussels and other benthic animals have been located at various active deep seafloor in close association with hydrothermal venting and coldseepage systems. It has been shown that these communities are nutritionally supported by chemoautotrophic bacteria which utilize chemical energy released during oxidation of hydrogen sulfide and other reduced forms of sulfur to synthesize organic carbon from carbon dioxide and water (Cavanaugh et al., 1981; Cavanaugh, 1983; Felbeck, 1981). The sulfur isotopic ratios of organic sulfur in hydrothermal vent-animals closely inherit those of the reduced sulfur in the hydrothermal fluids $(0 \pm 5 \%$, Fry $e t$ al., 1983), whereas those in the cold-seep communities represent biologically produced hydrogen sulfide $(-20 \%$ or lighter, Sakai et al., 1987). Therefore, the sulfur isotope ratios of large-size animals in the vent-communities should represent the isotopic ratios of reduced sulfur emitted from the vents and thus can be used to identify dominant sources of sulfur (e.g., magmatic or biogenic) in the areas, even before the reduced sulfur in the venting-fluid of the sites is sampled for sulfur isotopic analyses.

Recently, extensive surveys around the Japanese Islands by deep-tow cameras and videos and by submersibles located a low temperature hydrothermal vent area in Ogasawara Arc 
(Urabe et al., 1987), two cold seepage sites at Sagami Bay (Hashimoto et al., 1989), and four low- to high-temperature hydrothermal areas closely spaced in Mid-Okinawa Trough (Kimura et al., 1988a; Tanaka et al., 1988; Halbach et al. 1989). In all of these areas, prolific biological communities dominated by clams, mussels, crabs, squat lobsters and/or vestimentiferan tube worms were observed and sampled, but at no sites effort to obtain venting-fluid itself has yet been rewarded. We have analyzed the sulfur isotope ratios of reduced sulfur obtained from these sites, mostly in the form of vent-animal soft tissues, in order to assess whether biological communities are supported by volcanic hydrothermal or cold seep-type biogenic hydrogen sulfide. In this paper, the results so far obtained will be reviewed and discussed.

\section{Localities, Geological Settings and SAMPLE DESCRIPTION}

Table 1 summarizes the nature of samples analyzed and their localities, which are also plotted in Fig. 1. The geological settings of each locality and sample descriptions are briefly given below.

1. Pyrite, native sulfur and Bathymodiolus type mussel from Kaikata Caldera, Kaikata Seamount $\left(26^{\circ} 42^{\prime} \mathrm{N}, 141^{\circ} 05^{\prime} \mathrm{E}\right)$ : Kaikata Caldera is located on the easternmost summit of Kaikata Seamount, a submarine volcano of the IzuOgasawara Arc (Urabe et al., 1987). The caldera floor is about $930 \mathrm{~m}$ below sea-level, with a 500 $\mathrm{m}$ high central cone, where low-temperature hydrothermal activity has been found recently (Deep Sea Survey Group, 1988; Urabe et al., 1987; Yuasa et al., 1987; Ohtsuka et al., 1988; Naka et al., 1988; Hashimoto et al., 1988; Mitsuzawa et al., 1989). The last three authors cited above observed, by “'Shinkai 2000", emission of fluid more than $10^{\circ} \mathrm{C}$ warmer than ambient, from mounds at the western side of a crater-like depression of about $100 \mathrm{~m}$ diameter located on the central cone. Biological communities dominated by Bythoqraea-type white crabs, mussels, and bacterial mats were also observed in association with the warm water venting (Naka et al., 1988; Hashimoto et al., 1988; Deep Sea Survey Group, 1988). A biological community dominated by Bathymodiolus-type mussels occupied about $5 \times 5 \mathrm{~m}$ area on the top of the crater rim, from which the analyzed specimen (No. 1, Table 1, 175 $\times 55 \mathrm{~mm}$ in shell size having wet soft tissue of $58.6 \mathrm{~g}$ ) was collected. Although shimmering of water was not observed within the community bed, temperature at $30 \mathrm{~cm}$ below the sediment surface within the community was $18.5^{\circ} \mathrm{C}$, compared to $12.5^{\circ} \mathrm{C}$ at the same depth about $3 \mathrm{~m}$ outside of the community, which is similar to bottom seawater temperature (Mitsuzawa et al., 1989). Sandy sediment attached to the shell did not give $\mathrm{H}_{2} \mathrm{~S}$ when attacked by $\mathrm{HCl}$ but yielded $\mathrm{H}_{2} \mathrm{~S}$ with the $\mathrm{CrCl}_{2}$-bearing $\mathrm{HCl}$ (No. 2, Table 1). The latter $\mathrm{H}_{2} \mathrm{~S}$ was attributed to pyritic sulfur (see "Experimental").

Rock samples obtained by the submersible indicate that, unlike the andesitic caldera wall rocks, the central cone is composed of fresh glassy basalt (Urabe et al., 1987). Semiconsolidated volcanic sands picked up by "Shinkai 2000 " at the foot of the inner wall of the depression are covered with a few mm-thick iron-rich red precipitates and the inner portion gave strong smell of hydrogen sulfide (Naka et al., 1988). Semiconsolidated volcanic breccia, (No. 3 , Table 1) obtained at the same site yielded similarly strong hydrogen sulfide smell and grain boundaries were filled with fine crystalline pyrite. Volcanic sands rich in native sulfur (No. 4, Table 1, C-25), also semi-consolidated, were collected accidentally by the deep-tow vehicle, probably in the proximity to the above location during R/V Hakurei-Maru cruise in 1988 ( $\mathrm{T}$. Urabe, personal communication). These observations and samples clearly indicate that warm, hydrogen sulfide-rich fluid is coming out from the central cone of the caldera.

2. Calyptogena-type clams, Munidopsistype squat lobsters, and sulfide-bearing mangano-calcite from the northern foot of the eastern edge of the Iheya Ridge $\left(27^{\circ} 33^{\prime} \mathrm{N}\right.$, $\left.126^{\circ} 58^{\prime} \mathrm{E}\right)$, Iheya Basin, Mid-Okinawa Trough: Iheya Ridge is a $2 \mathrm{~km}$ long NEE-trending 


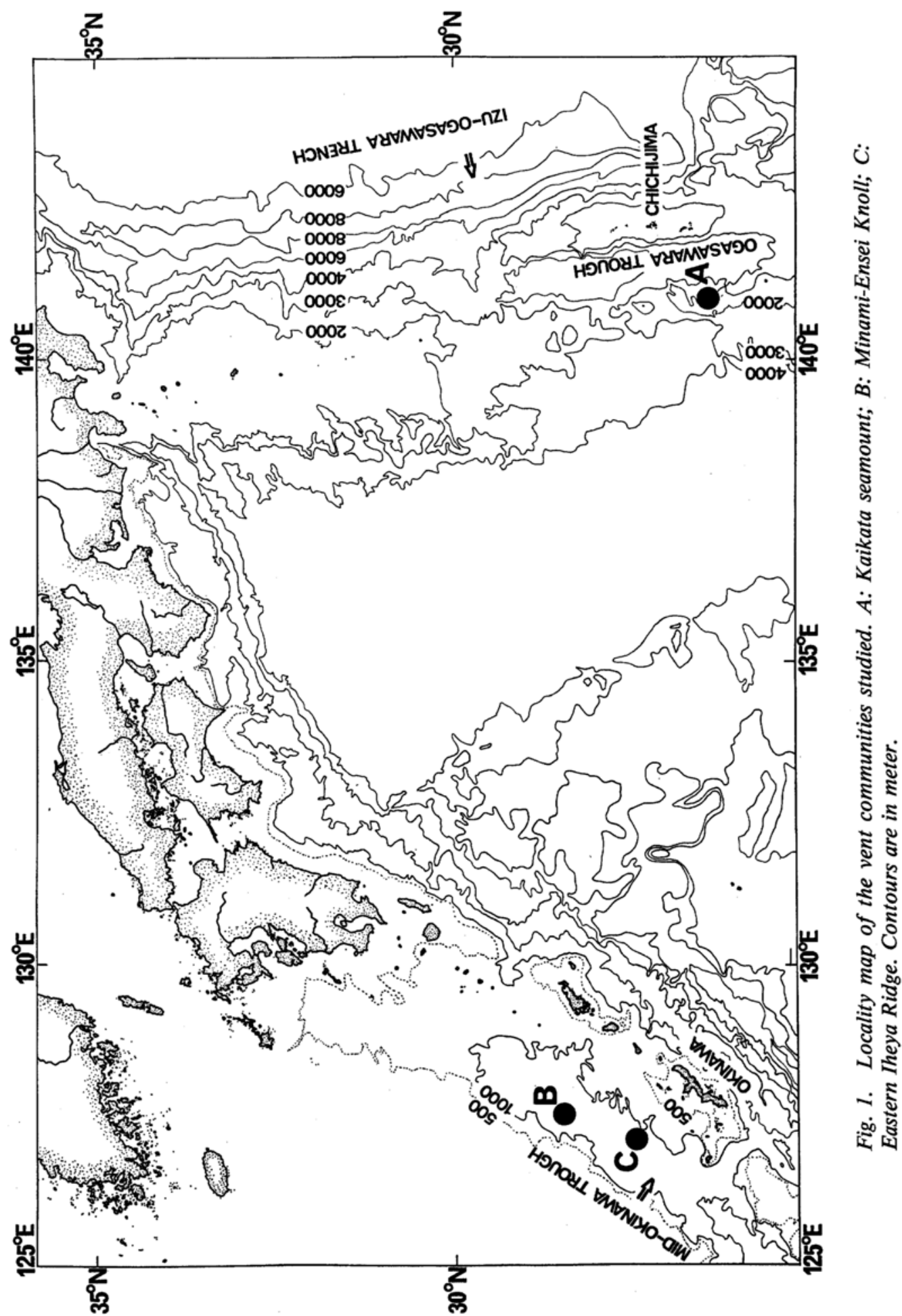


Table 1. $\quad \delta^{34} \mathrm{~S}$ values of vent animals and related sulfide species

\begin{tabular}{|c|c|c|c|}
\hline No. & Sample $^{*}\left(\right.$ locality $\left.^{* *}\right)$ & $\mathrm{S} \%$ & $\delta^{34} \mathrm{~S}_{\mathrm{CDT}} \%$ \\
\hline \multicolumn{4}{|c|}{ [Central cone, Kaikata Caldera, Ogasawara Arc.] } \\
\hline 1 & Bathymodiolus-type mussel (Dive \#340) & & \\
\hline $1-1$ & Mantle & 0.63 & -24.3 \\
\hline $1-2$ & Gill & 1.6 & -21.9 \\
\hline $1-3$ & Adductor & 0.47 & -25.5 \\
\hline $1-4$ & Foot & - & - \\
\hline $1-5$ & Viscera & 0.27 & -23.4 \\
\hline 2 & $\begin{array}{l}\text { Pyrite-1 (Dive \#340) } \\
\text { taken together with No. } 6\end{array}$ & & -22.5 \\
\hline 3 & Pyrite-2 (Dive \#341-1) & - & -9.8 \\
\hline 4 & Native sulfur $(C-25)$ & & -10.6 \\
\hline \multicolumn{4}{|c|}{ [Eastern Iheya Ridge, Okinawa Trough] } \\
\hline 5 & Calyptogena-type clam-1 (SO-56 DSE 135) & & \\
\hline $5-1$ & Mantle & 0.45 & -5.0 \\
\hline $5-2$ & Gill & 3.8 & -9.0 \\
\hline $5-3$ & Adductor & 0.64 & -11.5 \\
\hline $5-4$ & Foot & 0.53 & -6.0 \\
\hline $5-5$ & Viscera & 0.54 & -8.9 \\
\hline 6 & Calyptogena-type clam -2 (SO-56 DSE 135) & & \\
\hline 6-1 & Mantle & - & - \\
\hline 6-2 & Gill & 4.0 & -9.1 \\
\hline $6-3$ & Adductor & 0.56 & -10.8 \\
\hline $6-4$ & Foot & 0.64 & -9.1 \\
\hline $6-5$ & Viscera & 0.89 & -10.0 \\
\hline 7 & $\begin{array}{l}\text { Munidopsis-type squat lobster }-1 \\
\quad \text { (while soft tissue, SO-56 DSE 135) }\end{array}$ & 0.67 & -16.1 \\
\hline 8 & $\begin{array}{l}\text { Munidopsis-type squat lobster }-2 \\
\quad \text { (whole soft tissue, SO-56 DSE 135) }\end{array}$ & 0.94 & -15.8 \\
\hline 9 & Jarosite (SO-56 DSE 135) & - & -14.7 \\
\hline $\begin{array}{l}10 \\
\text { IMina }\end{array}$ & $\begin{array}{l}\text { Galena in Mangano-calcite (Dive \#366) } \\
\text { i-Ensei Knoll. Okinawa }\end{array}$ & [Minami-Ensei Knoll, Okinawa Trough] & +2.5 \\
\hline 11 & $\begin{array}{l}\text { 11-Ensei Knoll, Okinawa Trough] } \\
\mathrm{H}_{2} \mathrm{~S} \text { in bottom seawater just } \\
\text { above tube worm colony (Dive \#357) }\end{array}$ & $2.6 \mathrm{ppm}$ & -21.3 \\
\hline 12 & Vestimentiferan tube worm - 1 (Dive \#357) & & \\
\hline $12-1$ & Vestimentum & 0.88 & -24.3 \\
\hline $12-2$ & Trophosome & 2.6 & -25.4 \\
\hline 13 & Vestimentiferan tube worm -2 (Dive \#357) & & \\
\hline 13-1 & Vestimentum & 0.85 & -24.7 \\
\hline 13-2 & TVestimentum & 2.8 & -25.2 \\
\hline $13-3$ & Tube, 0 to $5 \mathrm{~cm}$ from top & 2.5 & -26.7 \\
\hline $13-4$ & Tube 45 to $50 \mathrm{~cm}$ from top & 2.2 & -26.6 \\
\hline $13-5$ & Tube 85 to $90 \mathrm{~cm}$ from top & 0.30 & -23.2 \\
\hline
\end{tabular}

*(Dive \#340) etc. refer to the JAMSTEC dive numbers of "Shinkai 2000", and (SO-56 DSE-135) to the dredge station number of $R / V$ Sonne cruise leg 56, 1988.

${ }^{*}$ For sample description, see text.

basaltic ridge on the axis of the Mid-Okinawa Trough Back-Arc Basin. During R/V Sonne 56 cruise which was conducted in June to July 1988, as a West Germany-Japan joint research (Halbach et al., 1989), varieties of vent animals including two live Calyptogena-type clams (Nos. 5 and 6, Table 1), about 20 live squat lobsters
(Nos. 7 and 8, Table 1), and about $10 \mathrm{~kg}$ of dead, broken shells of Calyptogena-type clams were obtained by dredge conducted at this site, together with fresh and hydrothermally altered basalts. One of the basaltic rocks was partly covered with yellow platy precipitates of natrojarosite (No. 9, Table 1). More extensive study 
of this area was conducted by deep-towed color video system of the Japan Marine Science and Technology Center (JAMSTEC) and by "Shinkai 2000" in August to September, 1988, which led to the discovery of active hydrothermal areas of about $1 \mathrm{~km}^{2}$ (Tanaka et al., 1988). Clear hydrothermal water of the maximum measured temperature of $220^{\circ} \mathrm{C}$ flew out actively from cracks and fissures developed on the seafloor. Hydrothermal solutions precipitate mangano-calcite-amorphous silica deposits disseminated with minor sulfides (galena and sphalerite). Sample No. 10 was collected by $T$. Tanaka of JAMSTEC during his dive \#366.

3. Tube worms and hydrogen sulfide-bearing bottom seawater from Depression B of MinamiEnsei Knoll, Okinawa Trough (Nos. 11-13, Table 1): Minami-Ensei Knoll, $28^{\circ} 24.50^{\prime} \mathrm{N}$, $127^{\circ} 38.00^{\prime} \mathrm{E}$, is on the northeastern extension of the Okinawa Back-Arc Basin, where many irregular shaped knolls give complicated topographic features. The top of Minami-Ensei $\mathrm{Knoll}$ is $550 \mathrm{~m}$ deep and is spotted by many small depressions of about $100 \mathrm{~m}$ depth and of $1000 \mathrm{~m}$ diameter. Dense biological communities dominated by mussels and clams were identified by the JAMSTEC deep-towed color video system in June 1988. Subsequently, two dives of "Shinkai 2000" were conducted by one of us ( J. H.) in August 1988 in order to investigate the biological communities. According to his unpublished report to JAMSTEC, dense communities, each about $3 \mathrm{~m}$ in diameter and dominated by several hundreds tube worms, were found within a small depression (Depression B) at the western part of the knoll. The area was covered with many large blocks of rock of unknown composition, of which those within 15 to $20 \mathrm{~m}$ away from the community show greyish white alteration. Fluid venting from coarse sandy floor and from fissures on rocks within and near-by the biological communities was identified by shimmering of water just above these seabed structures. Temperature of the shimmering water was $2.9^{\circ} \mathrm{C}$ higher than ambient $\left(7.0^{\circ} \mathrm{C}\right)$ at the maximum. Bottom seawater (No. 11, Table 1) collected right above one of the vestimentiferan tube worm colony gave strong odor of hydrogen sulfide (see Table 1 for analytical results). Tube worms, sample Nos. 12 and 13 in Table 1, were collected from this colony.

\section{EXPERIMENTAL}

Animal tissues, dissected into individual organs whenever possible, were washed in distilled water, freeze-dried, ground, and combusted in pressurized oxygen gas (about $30 \mathrm{~kg} / \mathrm{cm}^{2}$ ) using a Parr bomb. Sulfate in the combustion residue was leached out by distilled water and converted to barium sulfate. The sulfate concentrations in the leacheates were determined by ion-chromatography in order to calculate the sulfur contents in the dry soft tissues. Pure pyrite was oxidized with a $\mathrm{HNO}_{3}-\mathrm{Br}_{2}$ mixture and sulfate formed was precipitated as barium sulfate. Unseparable pyrite in sediments was attacked with $\mathrm{CrCl}_{2}$-bearing $\mathrm{HCl}$ (Zhabina and Volkov, 1978), after acid-soluble sulfides, if any, were removed by digestion with hot $6 \mathrm{~N} \mathrm{HCl}$. Evolved $\mathrm{H}_{2} \mathrm{~S}$ was fixed as $\mathrm{ZnS}$ and then oxidized to sulfate with $\mathrm{HNO}_{3}-\mathrm{Br}_{2}$ mixture. Sulfur dioxide for the isotopic ratio measurement was evolved from the barium sulfate using the technique of Yanagisawa and Sakai (1983). The sulfur isotopic ratios are reported in the familiar $\delta^{34} \mathrm{~S}$ values relative to Canon Diablo troilite. The analytical errors are $\pm 0.2 \%$ for $\delta^{34} S$ and \pm 10 percent for sulfur concentration, respectively.

\section{RESUlts}

The concentrations and isotopic ratios of sulfur in the sampes are summarized in Table 1 and are plotted in Fig. 2. For comparison, the ranges of $\delta^{34} \mathrm{~S}$ values previously reported for normal marine biota and animals of other hydrothermal and cold-seep communities are also included in the figure. The sulfur isotopic ratios of the animals of the present study are all negative, and variably and significantly deviated from those heavy values $(+15 \sim+20 \%)$ normally found for marine animals supported by photosynthetic 

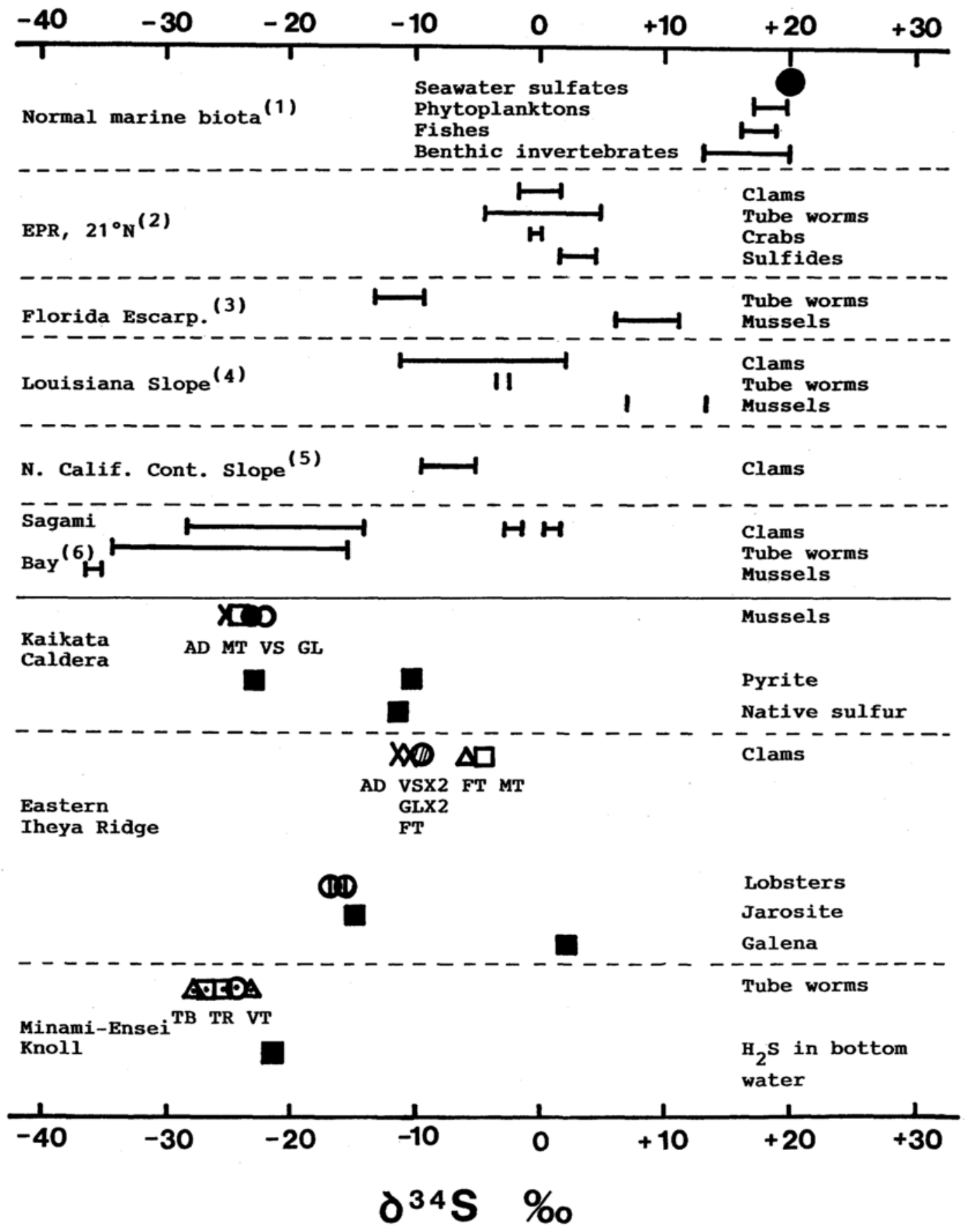

Fig. 2. $\delta^{34} S$ values of vent-animals and related sulfur species at hydrothermal and cold-seepage areas, (1) Fry (1983); (2) Fry et al. (1983); (3) Cary et al. (1989); (4) Brooks et al. (1987); (5) Kennicutt et al. (1989); (6) Sakai et al. (1987); Kim, E. S., unpublished data. GL: gill; AD: adductor; MT: mantle; FT: foot; VS: viscera; VT: vestimentum; TR: trophosome; TB: tube. 
food webs (Fry et al., 1983). This fact, together with the high sulfur contents, probably in the form of native sulfur, in the gills of clams and mussels and in the trophosome of tube worms, clearly indicate that these animals are supported by endosymbiosis with chemoautotrophic sulfur-oxidizing bacteria residing within these organs (Cary et al., 1989; Sakai et al., 1987). The sulfur isotopic ratios of these animal tissues should closely represent those in the venting fluids of each site.

As are described in "Localities, geological settings and sample description", Kaikata Caldera, eastern Iheya Ridge and Minami-Ensei Knoll are volcanically active sites and all the animal samples studied are from dense animal communities associated with warm to hot fluidventing. Thus, we would expect that the organic sulfur in these animals has $\delta^{34} \mathrm{~S}$ values simialr to volcanic sulfur values: -1 to $+5 \%$ for submarine basalts (Sakai et al., 1982; 1984) and 0 to $+12 \%$ for island arc basalts and andesites (Ueda et al., 1979; 1984). As a matter of fact, a sample of galena associated with carbonate precipitation collected at the eastern Iheya Ridge hydrothermal site (No. 10, Table 1) has a $\delta^{34} \mathrm{~S}$ value of $+2.5 \%$. Furthermore, the extensive polymetallic sulfide deposits, having pyrite of $\delta^{34} \mathrm{~S}$ of $+6.5 \pm 0.5 \%$, have been found on the northeastern slope of Izena Cauldron about 36 $\mathrm{km}$ south to the eastern Iheya Ridge hydrothermal site (Halbach et al., 1989). Active venting of hydrothermal fluid with temperatures higher than $130^{\circ} \mathrm{C}$ has also been confirmed at this site in 1988 (Kimura et al., 1988b; Nakamura et al., 1988). Therefore, the $\delta^{34} \mathrm{~S}$ values of magmatic sulfur of Okinawa Trough should be 0 to $+7 \%$.

On the contray to our expectation, however, the $\delta^{34} \mathrm{~S}$ values of the studied animals are much lower than the volcanic values. The large negative values found for the dissolved hydrogen sulfide $(-21.3 \%)$ in warm bottom seawater and associated tube worms $(-26.7 \%)$ at MinamiEnsei Knoll are similar to hydrogen sulfide produced by microbial reduction of seawater sulfate at organic-rich sediment/seawater interface (Sweeney, 1972). On the other hand, pyrite and native sulfur from Kaikata Caldera and animals from the eastern Iheya Ridge are intermediate between volcanic and microbial sulfide values. Then, our question is whether these sulfurs of variably negative $\delta^{34} \mathrm{~S}$ values can still be regarded as volcanic in origin or they are biogenic?

Another interesting feature to be noted is that at the eastern Iheya Ridge the Calyptogenatype clams have considerably heavier $\delta^{34} \mathrm{~S}$ values than the squat lobsters caught in the same dredge haul as the clams. This may imply that the isotopic ratios of reduced sulfur emitted are variable within a narrow zone of a thermal area. Alternatively, because the squat lobsters prey upon vent animals including clams, the difference may reflect isotope fractionation during passage of sulfur through food webs in ventcommunities. We will briefly return to this point later.

\section{Discussion}

Sulfur isotope fractionation during hydrothermal processes

Major sulfur species in submarine hydrothermal solution are sulfate and hydrogen sulfide. Because the light sulfur isotope is favored in hydrogen sulfide relative to sulfate under isotope exchange equilibrium, volcanic hydrogen sulfide may become to be significantly depleted in the heavy isotope compared to its source volcanic sulfur due to the isotope fractionation during hydrothermal processes.

The isotopic shift of hydrogen sulfide, $\Delta_{\mathrm{H}_{2} \mathrm{~s}}$, from the bulk sulfur in a hydrothermal system may be defined as follows:

$$
\begin{aligned}
\Delta_{\mathrm{H}_{2} \mathrm{~S}} & =\delta^{34} \mathrm{~S}_{\mathrm{H}_{2} \mathrm{~S}}-\delta^{34} \mathrm{~S}_{2 \mathrm{~S}} \\
& =-(1-x) 1000 \ln \alpha_{\mathrm{SO}_{4}-\mathrm{H}_{2} \mathrm{~S}}
\end{aligned}
$$

where $\delta^{34} \mathrm{~S}_{\Sigma \mathrm{S}}$ is the isotopic ratio of the bulk sulfur, or weighted average of sulfate and sulfide, $x$ is the fraction of hydrogen sulfide in the total sulfur, and $1000 \ln \alpha_{\mathrm{SO}_{4}-\mathrm{H}_{2} \mathrm{~S}}$ is the isotope fractionation factor between $\mathrm{SO}_{4}$ and sulfide species. The last mentioned is expressed as: 


$$
1000 \ln \alpha_{\mathrm{SO}_{4}-\mathrm{H}_{2} \mathrm{~S}}=\delta^{34} \mathrm{~S}_{\mathrm{SO}_{4}}-\delta^{34} \mathrm{~S}_{\mathrm{H}_{2} \mathrm{~S}}
$$

The experimental fractionation factor between dissolved sulfate and sulfide at $\mathbf{3 0 0}$ and $400^{\circ} \mathrm{C}$ is $+20 \%$ (Sakai and Dickson, 1978) and $+15 \%$ (Kamada et al., 1980), respectively. Extrapolation of these values gives a value of approximately $+28 \%$ as the fractionation factor at $200^{\circ} \mathrm{C}$ (see also Ohmoto and Lasaga, 1982). Therefore, from equation (1), it is expected that at $200^{\circ} \mathrm{C}$ andesitic to rhyolitic hydrothermal system of $+5 \%$ bulk sulfur may produce $\mathrm{H}_{2} \mathrm{~S}$ of $-23 \%$, if sulfate is dominant over sulfide due to high oxidation potential and if no seawater sulfate is introduced into the system.

However, the difficulty of this model lies in the fact that the venting fluid that supplies reduced sulfur to animal community could not be so much oxidizing as the model requires. The bottom seawater at Minami-Ensei Knoll, sample No. 11 in Table 1, for example, contains 0.081 $\mathrm{mM} \mathrm{H}_{2} \mathrm{~S}$ of $-21 \%$ and an excess enthalpy of $2.9 \mathrm{kcal} / \mathrm{kg}$ water. Assuming that this is a mixture of normal bottom seawater of this area and a hydrothermal end-member solution of an excess enthalpy of $200 \mathrm{kcal} / \mathrm{kg}$ water, the endmember should have approximately $5.3 \mathrm{mM}$ $\mathrm{H}_{2} \mathrm{~S}$. Using equation (1) and the fractionation factor between sulfate and sulfide at $200^{\circ} \mathrm{C}$ as given above, the sulfide fraction, $x$, to match the $\delta^{34} \mathrm{~S}_{2 \mathrm{~S}}$ of $+5 \%$ is calculated to be about 0.06 . Then, the total sulfate content of the endmember hydorthermal solution should be $(5.3 / 0.06) \times 0.94=83 \mathrm{mM}$. Such a high sulfate concentration (much higher than seawater sulfate concentration of $28 \mathrm{mM}$ ) does not seem to be realistic for seawater-derived hydrothermal solution, as has been documented by experimental seawater-basalt, -andesite or -rhyolite interaction (Bischoff and Dickson, 1975; Shiraki et al., 1987) and by fluid inclusion analyses of Kuroko ore deposits (Ohmoto et al., 1983).

In order to clarify the above relationship among sulfur isotope ratios, redox potential, and sulfur concentration in hydrothermal solutions, Fig. 3 was constructed under the assumptions: (1) all the sulfide and sulfate species are in isotopic and chemical equilibria, (2) calcium concentration is constant as controlled by seawaterrock interaction and (3) the solution is saturated with anhydrite. The third assumption came from the fact that many hydrothermal solutions so far studied were saturated or near-saturated with anhydrite (Sakai and Matsubaya, 1974). Under the second and third assumptions, the sulfate concentration also becomes to be constant at a given temperature and solution chemistry, because the solubitity product of anhydrite is a function of temperature and solution composition. The sulfide/sulfate ratio which is controlled by redox potential then determines the total sulfide concentration.

According to Marshall and Slusher (1968), formal solubility product of anhydrite in a standard seawater at $200^{\circ} \mathrm{C}$ is $5 \times 10^{-5}(\mathrm{~mol} / \mathrm{kg})^{2}$. Assuming the hydrothermal solution to have the same ionic strength as standard seawater, this value was used in Fig. 3. Calcium concentration of submarine hydrothermal solution depends on various factors, such as the calcium content of rocks and/or sediments with which seawater reacts, the water/rock ratio and temperature of reaction. It generally decreases as rock composition changes from basic to acidic and with increasing effective water/rock ratio, if other conditions are the same. Two calcium concentrations are selected in Fig. 3; $20.8 \mathrm{mM}$, the highest value so far reported for hydrothermal systems of at $21^{\circ} \mathrm{N}$, East Pacifie Rise (Von Damm et al., 1985) where basaltic rocks are reacted with seawater, and $6.8 \mathrm{mM}$, which is similar to that in seawater and was obtained when seawater was experimentally reacted with rhyolite (Shiraki et al., 1987). Using the formal solubility product mentioned above, the sulfate concentration in the hypothetical hydrothermal solution was calculated to be $2.4 \mathrm{mM}$ for basaltic system and $7.4 \mathrm{mM}$ for rhyolitic system. These values were used to construct the bottom horizontal scales of Fig. 3 which express the sulfide sulfur contents in solution at different $\mathrm{SO}_{4} / \Sigma \mathrm{S}$ ratios. The source of sulfur in a submarine hydrothermal system is two-fold, magmatic sulfur and seawater sulfate; the $\delta^{34} \mathrm{~S}$ values of the bulk sulfur in the sub- 


\section{$\mathrm{SO}_{4}=/ \Sigma \mathrm{S}$}

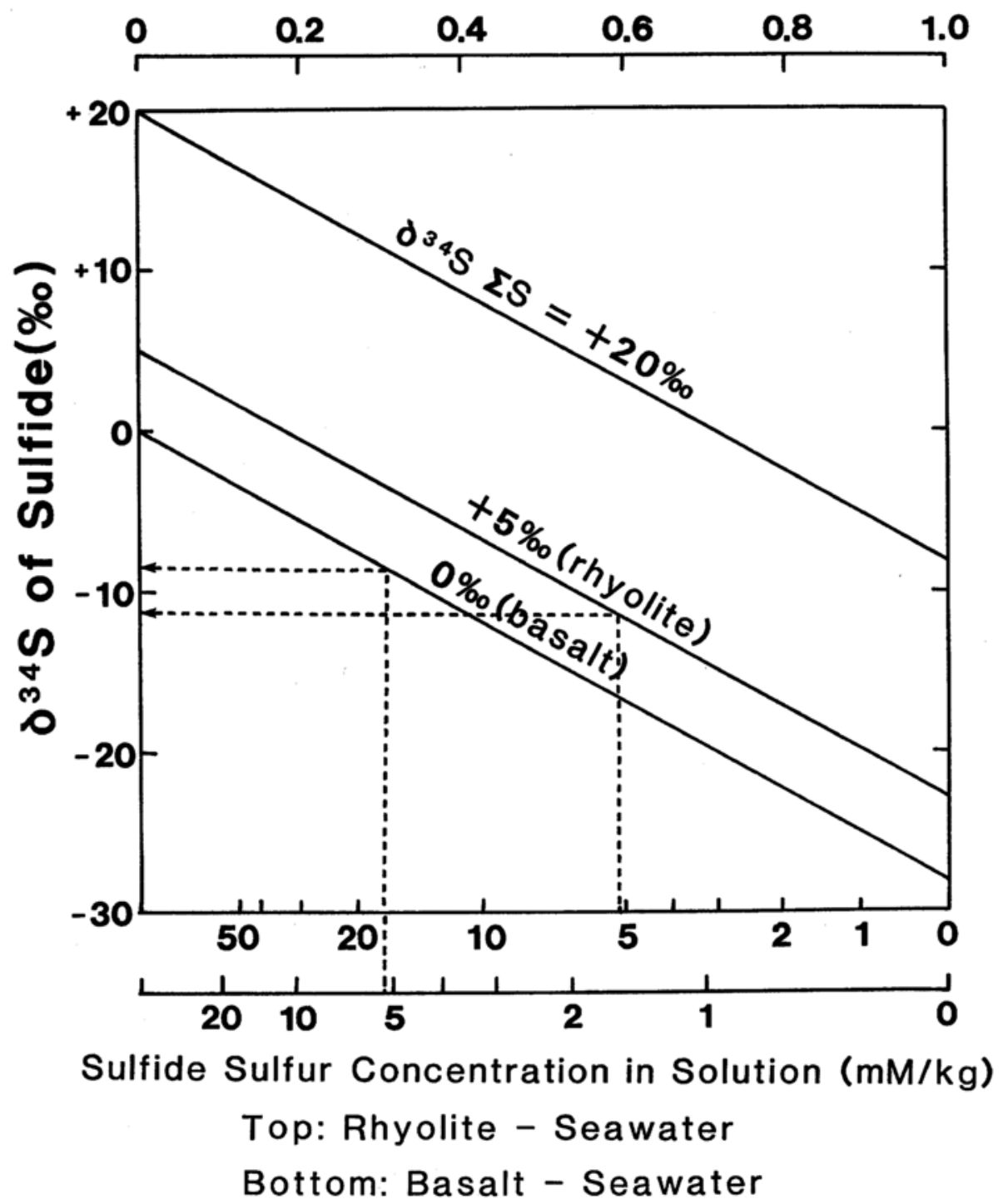

Fig. 3. Relationship among $\delta^{34} \mathrm{~S}$ of sulfide sulfur, $\mathrm{SO}_{4} / \mathrm{S}$ ratio and sulfide sulfur concentration in anhydritesaturated solution produced by seawater-basalt and seawater-rhyolite reaction at $200^{\circ} \mathrm{C}$. Dashed lines indicate the lowest possible $\delta^{34} \mathrm{~S}$ values of hydrogen sulfide in hypothetical hydrothermal end-member solution of 5.3 $\mathrm{mM} \mathrm{H}_{2} \mathrm{~S} / \mathrm{kg}$ at $200^{\circ} \mathrm{C}$ in contact with basalt and rhyolite, respectively. For details, see text.

marine hydrothermal system is determined by the mixing ratio of the two components. In Fig. 3 , two values for magmatic sulfur are shown, $0 \%$ for basaltic sulfur and $+5 \%$ for rhyolitic sulfur.

Figure 3 indicates that at $200^{\circ} \mathrm{C}$ and under the conditions depicted above, $\delta^{34} \mathrm{~S}$ values of hydrogen sulfide may vary from +20 to $-28 \%$. However, the sulfide concentration in the endmember fluid must be high in order to maintain the biological communities alive. At the Minami-Ensei Knoll, the $\delta^{34} \mathrm{~S}$ value of the 
hydrogen sulfide cannot be lighter than $-11 \%$ in rhyolite-seawater system or than $-9 \%$ in basalt-seawater system in order for the fluid to have, at least, $5.3 \mathrm{mM} \mathrm{H}_{2} \mathrm{~S}$ as was estimated above. These lowest possible $\delta^{34} \mathrm{~S}$ values for both systems would become lower with decreasing temperature of reaction. However, the chemical and isotopic equilibria among sulfur species may become less realistic at temperature below $200^{\circ} \mathrm{C}$.

Microbial origin of hydrogen sulfide supporting the mussels at Kaikata Caldera and the tube worms at Minami-Ensei Knoll

The foregoing discussion suggests that the organic sulfur of the mussel from the Kaikata Caldera and that of the vestimentiferan tube worms from the Minami-Ensei Knoll cannot be volcanic in origin but should be attributed to hydrogen sulfide produced by microbial reduction of seawater sulfate at sediment/seawater interface. Such reduction produces hydrogen sulfide of -20 to $-70 \%$ (Sweeney, 1972; Kim, E. S., unpublished).

Origins of sulfur in the vent-animals with intermediate isotope ratios

The pyrite and native sulfur from the Kaikata Caldera studied in this research show almost the identical isotope ratios to those previously reported for the similar pyrite samples from the Kaikata Caldera (-11.7 -13.9\%, Urabe et al., 1987). This suggests that the hydrogen sulfide of about -10 to $-12 \%$ has widely been issued from the caldera floor. Urabe et al. (1987) also measured the $\delta^{34} \mathrm{~S}$ values of +1.2 and $+0.9 \%$ for pyrite in quartzveinlet found in hydrothermally altered andesite dredged from the caldera. They concluded that there are two sources of sulfide sulfur in the caldera: andesite magma $(+1 \%)$ and partial chemical reduction of seawater sulfate in hydrothermal zone $(-10 \sim-12 \%)$. However, as is shown in Fig. 3, it is difficult to form sulfide of -10 to $-12 \%$ by partial chemical reduction of seawater sulfate followed by isotopic equilibration at $200^{\circ} \mathrm{C}$. The difficulty would not be resolv- ed even if the temperature is reduced to $150^{\circ} \mathrm{C}$. It is neither possible kinetically because the kinetic isotope effect of chemical sulfate reduction is smaller than $-20 \%$ at temperatures higher than $150^{\circ} \mathrm{C}$ (Grinenko et al., 1969).

Figure 3 indicates that the sulfide of $-10 \%$ would form if magmatic sulfur $(0 \sim 5 \%)$ is partially oxidized and the isotope equilibration is established between sulfate and sulfide at hydrothermal temperature. However, because oxidation in submarine hydrothermal system would proceed only with invasion of oxygenated bottom seawater and thus isotopically heavy seawater sulfate into the system, the $\delta^{34} \mathrm{~S}$ of bulk sulfur would increase, making it difficult to form sufficiently light hydrogen sulfide.

On the other hand, the emission of microbial hydrogen sulfide supporting a mussel-dominated community at the Kaikata Caldera strongly suggests that these intermediate isotopic values are formed by mixing of magmatic and microbial hydrogen sulfides. Although detailed modeling of the system has yet to wait for future study, such mixing would occur when biogenic pyrite formed in shallow sediments of the caldera was reworked with magmatic hydrothermal activity. Therefore, pyrite and native sulfur of varying $\delta^{34} \mathrm{~S}$ from near-zero to $-25 \%$ could have formed within the caldera depending on the extent of magmatic activity and hydrological condition that controls the mixing ratios of two sulfurs.

At the eastern Iheya Ridge hydrothermal area, no sulfide formation except for the disseminated fine sulfides (galena and/or sphalerite) in carbonate precipitation has been recognized. However, the $\delta^{34} \mathrm{~S}$ of galena $(+2.5 \%$ No. 10 , Table 1) may be taken to represent the magmatic value of this area, as the major volcanic rocks of this area is basalt. Then, again as in the Kaikata Caldera, the hydrogen sulfide that supports vent communities here also is most likely a mixture of magmatic and microbial hydrogen sulfides. Different mixing ratios within a hydrothermal area would produce $\mathrm{H}_{2} \mathrm{~S}$ and therefore vent animals of variable $\delta^{34} \mathrm{~S}$. The fact that the squat lobsters of this area 
which prey upon vent animals have significantly lighter $\delta^{34} \mathrm{~S}$ values than the clams supports this contention.

The sulfate of jarosite (No. 9, Table 1) collected from the oxidized basalt surface has a similar isotopic value to the squat lobsters. Therefore, the jarosite sulfate did not come from seawater but must have formed from a precursor sulfide. The precursor sulfide may have had the same isotopic value as the jarosite. Alternatively, the precursor had a $\delta^{34} \mathrm{~S}$ lighter than the jarosite value but during the oxidation process the isotopic value may have been raised to the present value by mixing with seawater sulfate. In any case, the jarosite of the light isotopic value provides further evidence for the wide occurrence of isotopically light, nonmagmatic hydrogen sulfide in this area.

\section{High production and transport rates of microbial hydrogen sulfide at hydrothermal areas}

Although the magnitude of sulfur flux required to maintain dense animal communities at vent sites is still open to question, chemosynthetic sulfur bacteria that consumes thiosulfates or sulfides as its energy source produce 0.4 to $0.8 \mathrm{~mol}$ of organic carbon per mol sulfur oxidized (Kelly, 1982). Similar carbon to sulfur ratios have been measured for the growth efficiency of endosymbiotic sulfide-oxidizing bacteria hosted by Solemya reidi, a bivalve inhabiting in shallow, reducing marine environment (Anderson et al., 1987). On the other hand, oxygen consumption rate of a Calyptogena soyoae, a giant clam hosting sulfur oxidizing bacteria, collected from the Hatsushima site, Sagami Bay, was 5$16 \mu \mathrm{mol}$ per hour per a clam of $50 \mathrm{~g}$ wet soft tissue (Koike et al., 1988). Similar values had also been reported by previous investigators for hydrothermal vent animals (Williams et al., 1981).

Assuming all the oxygen consumed was utilized for combustion of organic carbon supplied by the endosymbiotic bacteria, the clam requires $(0.005 \sim 0.0016) \times 24=0.12 \sim 0.38 \mathrm{mmol}$ of organic carbon per day or $(0.12 \sim 0.38)$
$/(0.4 \sim 0.8)=0.15 \sim 0.95 \mathrm{mmol}$ of reduced sulfur per day. At the Minami-Ensei Knoll, 200 to 300 tube worms of about $10 \mathrm{~g}$ wet soft tissue were observed within a circular community bed of about $3 \mathrm{~m}$ diameter, or $\mathbf{3 0}$ to 40 tube worms per $\mathrm{m}^{2}$ (Hashimoto, unpublished diving report of JAMSTEC). Such a community would require approximately 0.9 to $8 \mathrm{mmol}$ of reduced sulfur $/$ day $/ \mathrm{m}^{2}$, if the above estimated sulfur consumption rate of the Calyptogena-type clam is taken to be applicable to tube worms. Such a high microbial reduction rate of sulfate has been estimated in unusually reducing environments such as at Black Sea and Baltic Sea (2.3 3.6 and $5.3 \sim 14 \mathrm{mmol} \mathrm{S} /$ day $/ \mathrm{m}^{2}$, respectively, Skyring, 1987) and some of the continental shelves (Skyring, 1987). Production rate of hydrogen sulfide at normal organic-rich open seafloor is an order of magnitude or two smaller than these values (Volkov and Rozanov, 1983).

If the hydrogen sulfide content in the bottom seawater just above the tube worm community at the Minami-Ensei Knoll $(0.081 \mathrm{mM})$ is taken to represent that of venting-fluid which supports the community, the amount of sulfur that is contained in $1 \mathrm{~cm}$ long water column of $1 \mathrm{~m}^{2}$ cross section is $0.8 \mathrm{mmol}$. Therefore, the venting rate should be, at minimum, $(0.9 \sim 8) / 0.8=1 \sim 10$ $\mathrm{cm}$ per day. The shimmering of water observed at the community bed, however, suggests that the fulid was venting within a confined area at a higher rate than above and consequently, before mixing with ambient seawater, it had a higher sulfide concentration than that measured. In any case, the venting fluid must have passed through environment in which hydrogen sulfide is generated with a sufficiently high rate to maintain the sulfide flux estimated above. Such an environment must be sufficiently rich in organic matter and porous enough to allow a necessary supply of sulfate from circulating seawater.

Although detailed information on sedimentological structures of the studied areas is lacking, a high rate of accumulation of volcaniclastic sediments of these areas would be responsible for the formation of porous channels through which convective seawater circulation may be 
driven by geothermal heat gradient. At this moment, however, unusually high rate of accumulation of organic materials is difficult to explain. An attractive model to be tested in future works is that the present animal communities depend on the organic materials which were accumulated by earlier generations of vent communities and were accidentally buried to a shallow depth by volcanic fallout. The previous vent communities may have been formed during a period of more active volcanism or under environment similar to a period of the present low volcanic activity. The microbial hydrogen sulfide becomes to be an important source of sulfur for vent-communities to survive during periods of "sulfur famine" that would occur during low volcanic activity.

\section{Conclusions}

The vent-community animals (clams, mussels, squat lobsters and tube worms) collected from two volcanically active sites of the Mid-Okinawa Trough and one of the Ogasawara Arc all indicated their nutritional dependence(at least partially to completely) on hydrogen sulfide of microbial origin. The present results strongly suggest that in volcanically active areas a certain biogeochemical and hydrological environment often forms in which a high rate of microbial production of hydrogen sulfide and its efficient transport to confined surface zones are favorably maintained and dense biological communities grow depending on it. A high heat-flow which brings seawater into circulation through porous volcaniclastic sediments is evidently one of the driving forces of such a system. However, in order to maintain such a high flux of hydrogen sulfide for a sufficiently long period of time to allow the biological communities to grow, the system requires sufficient accumulation of organic materials within the system. In this context, it was suggested that organic materials accumulated by older communities could efficiently be used to produce hydrogen sulfide and support younger communities which otherwise would not survive the periods of low volcanic activity.

Acknowledgments-We thank Dr. T. Tanaka and Mr. K. Mitsuzawa of JAMSTEC , Dr. T. Urabe, Geological Survey of Japan and Mr. Y. Kato, Hydrographic Department, Maritime Safety Agency for their kindly supplying us with the samples analysed in this study and the relevant information. Our thanks are also due to Dr. H. Hotta of JAMSTEC, the pilots and operation team members of "Shinkai 2000 " and the captains and crew of the tendership Natsushima and R/V Sonne for their cooperation and enthusiasm througout the study. Dr. T. Horikoshi, Chiba University and Mrs. K. Endow, University of Tokyo helped us in dissection of clams and mussels. The isotopic ratio measurements were made possible through the courtesy of Drs. H. Shimazaki and N. Shikazono, University of Tokyo and Dr. Y. Matsuhisa, Geological Survey of Japan. We are greatly indebted to Drs. M. Kusakabe, Okayama University and N. Handa, Nagoya University for their critical readings of the manuscript.

\section{REFERENCES}

Anderson, A. E., Childress, J. J. and Favuzzi, J. A. (1987) Net uptake of $\mathrm{CO}_{2}$ driven by sulphide and thiosulphate oxidation in the bacterial symbiontcontaining clam Solemya reidi. J. Exp. Biol. 133, 131.

Bischoff, J. L. and Dickson, F. W. (1975) Seawaterbasalt interaction at $200^{\circ} \mathrm{C}$ and 500 bars: implications for origin of sea-floor heavy-metal deposits and regulation of seawater chemistry. Earth Planet. Sci. Lett. 25, 385-397.

Brooks, J. M., Kennicutt, M. C. II, Fisher, C. R., Macko. S. A., Cole K., Childress. J. J., Bidigare, R. R., and Vetter, R. D. (1987) Deep-sea hydrocarbon seep communities: evidence for energy and nutritional carbon sources. Science 238, 1138-1142.

Cary, C., Fry, B., Felbeck, H. and Vetter, R. D. (1989) Multiple trophic resources for a chemoautotrophic community at a cold water brine seep at the base of the Florida Escarpment. Mar. Biol. 100, 411-418.

Cavanaugh, C. M., Gardiner, S. L., Jones, M. L., Jannasch, H. W. and Waterbury, J. B. (1981) Prokaryotic cells in the hydrothermal vent tube worm Riftia pachyptila Jones: possible chemoautotrophic symbionts. Science 213, 340-342.

Cavanaugh, C. M. (1983) Symbiotic chemoautotrophic bacteria in marine invertebrates from sulphide-rich habitats. Nature 302, 58-61.

Deep Sea Survey Group (1988): Preliminary report of 
deep tow survey in Kaikata Sea Mount (DN87-3MCS). JAMSTEC Tech. Rep. 19, 223-230. (in Japanese with English abstract)

Felbeck, H. (1981) Chemoautotrophic potential of the hydrothermal vent tube worm Riftia pachyptila Jones (Vestimentifera). Science 213, 336-338.

Fry, B. (1983) Fish and shrimp migrations in the northern Gulf of Mexico analyzed using stable $\mathrm{C}, \mathrm{N}$, and $\mathrm{S}$ isotope ratios. Fish. Bull. 81, 789-801.

Fry, B., Gest, H. and Hayes, J. M. (1983) Sulphur isotopic compositions of deep-sea hydrothermal vent animals. Nature 306, 51-52.

Grinenko, V. A., Grinenko, L. N. and Zagryazhskaya, G. D. (1969) Kinetic isotope effect in high temperature reduction of sulfate. Geokhimiya, No. 4, 484-491.

Halbach, P., Nakamura, Ko-ichi, Wahsner, M., Lange, J, Sakai, H., Kaselitz, L., Hansen, R.-D., Yamano, M., Post, J., Prause, B., Seifert, R., Michaelis, W., Teichmann, F., Kinoshita, M., Marten, A., Ishibashi, J., Czerwinski, S., and Blum, N. (1989) Probable modern analogue of Kuroko-type massive sulphide deposits in the Qkinawa Trough back-arc basin. Nature 338, 496499.

Hashimoto, J., Hotta, H., and Deep Sea Survey Group (1988) On the biological communities found at the vicinity of the central cone of the Kaikata Caldera, west of Chichijima Island, Ogasawara. Abstact Papers, the 5th Symposium of 'Shinkai 2000 study, JAMSTEC, 87-88 (Japanese).

Hashimoto, J, Ohta, S., Tanaka, T., Matsuzawa, S. and Sakai, H. (1989) Deep-sea communities dominated by the giant clam, Calyptogena soyoae, along the slope foot of Hatsushima Island, Sagami Bay, central Japan. Paleogeogr. Paleoclimatol. Paleoecol. 71, 179-192.

Kamada, E., Sakai, H. and Kishima, N. (1980) Experimental study of sulfur isotope exchange between $\mathrm{SO}_{4}^{2-}$ and $\mathrm{H}_{2} \mathrm{~S}$ (aqueous) at $400^{\circ} \mathrm{C}$ and 1000 bars water pressure. Papers of the Institute for Thermal Springs Research, Okayama Univ., No. 50, 115 (in Japanese with English abstract).

Kelly, D. P. (1982) Biochemistry of the chemolithotrophic oxidation of inorganic sulphur. Phil. Trans. R. Soc. Lond. B 298, 499-528.

Kennicutt, M. C. II, Brooks, J. M., Bidigare, R. R., McDonald, S. J., Adkinson, D. L. and Macko, S. A. (1989) An upper slope "cold" seep community: northern California. Limnol. Oceanogr. 34, 635640.

Kimura, M., Uyeda, S., Kato, Y., Tanaka, T., Yamano, M., Gamo, T., Sakai, H., Kato, S., Izawa, E., and Omori, T. (1988a) Active hydrothermal mounds in the Qkinawa Trough backarc basin,
Japan. Tectonophysics 145, 310-324.

Kimura, M., Ando, M., Kyo, S-K., Tanaka, T., Naka, J., Omori, T., Izawa, E., and Kato, Y. (1988b) Topography, ore deposits and biomass in the mid-Okinawa Trough hydrothermal area. Abstract Paper s, the 5th Symposium of "Shinkai 2000" Study, JAMSTEC, 72-78 (Japanese).

Koike, I., Shirayama, Y., Gamo, T. and Sakai, H. (1988) Respiration rate of Calyptogena soyoae obtained from the Calyptogena communities at the Hatsushima site. JAMSTEC Deep-sea Rep. No. 4, 233-237 (in Japanese with English abstract).

Marshall, W. L., and Slusher, R. (1968) Aqueous systems at high temperature. Solubility to $200^{\circ} \mathrm{C}$ of calcium sulfate and its hydrates in sea water and saline water concentrates and temperature-concentration limits. J. Chem. Eng. Data 13, 83-93.

Mitsuzawa, K., Momma, H., Hotta, H. and Deep-Sea Survey Group (1989) Characteristics of water temperature and current around the submarine caldera in Kaikata Seamount. JAMSTEC Tech. Rep. 21, 110 (in Japanese with English abstract).

Naka, J., Mitsuzawa, K. and Deep-Sea Survey Group (1988) Geology of the Kaikata Caldera and its vicinity of the Kaikata Seamount, west of Chichijima Island, Ogasawara. Abstract Papers, the 5th symposium of 'Shinkai 2000' Study, JAMSTEC, 8586 (Japanese).

Nakamura, K., Urabe, T., Marumo, K., Aoki, M. and Kanazawa, Y. (1988) On the hydrothermal ore deposits of the Izena Cauldron, Okinawa Trough. Abstract Papers, the 5th Symposium of "Shinkai 2000"' Study, JAMSTEC, 67-70 (Japanese).

Ohmoto, H. and Lasaga, A. C. (1982) Kinetics of reactions between aqueous sulfates and sulfides in hydrothermal systems. Geochim. Cosmochim. Acta 46, 1727-1745.

Ohmoto, H., Mizukami, M., Drummond, S. E., Eldridge, 'C. S., Pisutha-Arnond, and Lenagh, T. C. (1983) Chemical processes of Kuroko formation. Econ. Geol. Monogr. 5., 570-604.

Ohtsuka, K., Tsuchiya, T. and Hashimoto, J. (1988) Development and operation of the deep-towed color video system. JAMSTEC Tech. Rept No. 19, 249-262 (in Japanese with English abstract) Sakai, H. (1968) Isotopic properties of sulfur compounds in hydrothermal processes. Geochem. J. 2, 29-49.

Sakai, H. and Matsubaya, Q. (1974) Isotopic geochemistry of the thermal waters of Japan and its bearing on the Kuroko ore solutions. Econ. Geol. 69, 974-991.

Sakai, H. and Dickson, F. W. (1978) Experimental determination of the rate and equilibrium fractionation factors of sulfur isotope exchange between sulfate and sulfide in slightly acid solutions at 
$300^{\circ} \mathrm{C}$ and 1000 bars. Earth Planet. Sci. Lett. 39, 151-161.

Sakai, H., Gamo, T., Endow, K., Ishibashi, J., Ishizuka, T., Yanagisawa, F., Kusakabe, M., Akagi, T., Igarashi, G., and Ohata, S. (1987) Geochemical study of the bathyal seep communities at the Hatsushima site, Sagami Bay, Central Japan. Geochem. J. 21, 227-236.

Sakai, H., Ueda, A., Casadevall, T. J. and Moore, J. G. (1982) Chemistry and isotopic ratios of sulfur in basalts and volcanic gases at Kilauea Volcano, Hawaii. Geochim. Cosmochim. Acta 46, 729-738.

Sakai, H., Dẻs Marais, D. J., Ueda, A., and Moore, J. G. (1984) Concentrations and isotope ratios of carbon, nitrogen, and sulfur in ocean-floor basalts. Geochim. Cosmochim. Acta 48, 2433-2441.

Shiraki, R., Sakai, H., Endoh, M. and Kishima, N. (1987) Experimental studies on rhyolite- and andesite-seawater interactions at $300^{\circ} \mathrm{C}$ and 1000 bars. Geochem. J. 21, 139-148.

Sweeney, R. B. (1972) Pyritization during diagenesis of marine sediment. PhD. Thesis, University of California, Los Angeles.

Skyring, G. W. (1987) Sulfate reduction in coastal ecosystems. Geomicrobiol. J. 5, 295-374.

Tanaka, T., Hotta. H., and Deep Sea Survey Group (1988) Hydrothermal activity and fine topography of Iheya Basin, Okinawa Trough. Abstract Papers, the 5th Symposium of "Shinkai 2000" Study, JAMSTEC, 79-81 (in Japanese).

Ueda, A. and Sakai, H. (1984) Sulfur isotope study of Quaternary volcanic rocks from the Japanese Islands Arc. Geochim. Cosmochim. Acta 48, 18371848.

Ueda, A., Sakai, H. and Sasaki, A. (1979) Isotopic composition of volcanic sulfur from Japan. Geochem. J. 13, 269-275.

Urabe, T., Yuasa, M., Nakao, S. and on-board scientists (1987) Hydrothermal sulfides from a submarine caldera in the Shichito-Iwojima Ridge, Northwestern Pacific. Mar. Geol. 74, 295-299.

Volkov, I. I. and Rozanov, A. G. (1983) The sulphur cycle in oceans. I. Reservoirs and fluxes. The Global Biogeochemical Sulphur Cycle, Ivanov, M. V. and J. K. Freny eds., SCOPE 19 John Wiley, Chichester, 358-448.

Von Damm, K. L., Edmond, J. M., Grant, B., Measures, C. I., Walden, B. and Weiss, R. F. (1985) Chemistry of submarine hydrothermal solutions at $21^{\circ} \mathrm{N}$, East Pacific Rise. Geochim. Cosmochim. Acta 49, 2197-2220.

Williams, P. M., Smith, K. L., Druffel, E. M. and Linick, T. W. (1981) Dietary carbon sources of mussels and tubeworms from Galapagos hydrothermal vents determined from tissue ${ }^{14} \mathrm{C}$ activity. Nature 292, 448-449.

Yanagisawa, F. and Sakai, H. (1983) Preparation of $\mathrm{SO}_{2}$ for sulfur isotopic ratio measurements by thermal decomposition of $\mathrm{BaSO}_{4}-\mathrm{V}_{2} \mathrm{O}_{5}-\mathrm{SiO}_{2}$ mixture. Anal. Chem. 55, 985-987.

Yuasa, M., Urabe, T., and Murakami, F. (1987) Hydrothermal alteration zone in Kaikata Caldera, Izu-Qgasawara Arc. Chishitsu News No. 391, 1-8 (Japanese).

Zhabina, N. N. and Volkov, I. I. (1978) A method of determination of various sulfur compounds in sea sediments and rocks. Environmental Biogeochemistry and Geomicrobiology, Vol. 3, Methods, Metals and Assessment. Krumbein, W. E. ed., 735-745. Ann Arbor Science Publ. 